\title{
DON TOXIN MENNYISÉGÉNEK VÁLTOZÁSA KOVÁSZOS TÉSZTÁBAN
}

\author{
Ács Katalin - Ács Erika - Varga Mónika - Tóth Beáta - Mesterházy Ákos
}

\begin{abstract}
Absztrakt: Gabonák és a belölük készült élelmiszerek szabad DON mennyiségét rendeletek szabályozzák annak egészségügyi kockázata miatt. Ismert, hogy a DON toxinok kötött formában is előfordulhatnak, melyek forrásai lehetnek szabad DON képződésnek fermentációs hidrolízis révén. Kísérleteinkben azt vizsgáltuk, hogy a hosszú kovászos technológia miként befolyásolhatja a szabad DON tartalmának mennyiségét. Habár a lisztek előzetes vizsgálata során nem mértünk jelentős mennyiségủ ismert kötött, ill. származék DON toxint, mégis szignifikáns DON növekedést (35\%) tapasztaltunk már 1 napos fermentációt követöen is. Vizsgáltuk, hogy mi lehet az eredete a nagymértékü DON növekedésnek, valamint vizsgáltuk az élesztő mennyiségének befolyásoló hatását a szabad DON megjelenésében. Eredményeink azt mutatják, hogy lehet olyan ismeretlen DON prekurzor, amelyböl jelentős mennyiségű DON képes felszabadulni fermentációs folyamatoknak köszönhetően.
\end{abstract}

Abstract: Content of DON toxin in cereals and cereal based foods is regulated because of its health risk. It is published that DON can be found in masked form what can be a source of DON formation by fermentation. The aim of this study was monitoring the changes of DON content in a longfermentation sourdough baking technology. Although no masked DON or DON derivatives were found in the flour, we have measured significance DON increase (35\%) even after one day of fermentation. The source of this considerable DON increase and the influence of the amount of yeast on DON content were studied. The results show that unpublished DON precursor can be the source of DON formation in our fermentation process.

Kulcsszavak: kovász, mikotoxin, kötött DON

Keywords: sourdough, mycotoxin, masked DON

\section{Bevezetés}

Gabonák szabad DON (deoxynivalenol) toxin tartalma egészségügyi kockázatot jelenthet mind az állatok mind az ember számára (Zain, 2010; Yazar et al., 2008). $\mathrm{Az}$ élelmiszerekben elöforduló toxin határértékeit az EU régióban elöírások szabályozzák 2006 óta (EC 881/2006; EC 1126/2006). Ezek a határértékek a DON toxin ún. szabad formájára vonatkoznak. Ugyanakkor ismert, hogy a DON molekula kötött formában is előfordulhat, melyek a rutinszerü DON analízise során nem detektálhatók. E kötött formák képződését a növények detoxifikációs rendszerének tulajdonítják, ahol a növény - védekezésképpen a DON toxinnal szemben különböző csoportokat köt a DON toxinhoz (Berthiller et al., 2013). E „kötött” vagy „,rejtett” DON vegyületek ugyan kevésbé toxikusak mint a DON szabad formája, de jelenlétük mégis kockázatot jelenthet oly módon, hogy forrásai lehetnek a szabad DON molekulának, mint prekurzorok (Dall'Asta et al., 2016). Leggyakrabban előforduló kötött DON a DON-3-glükozid, de ismert még a DON-diglükozid, DONoligoglükozid, DON-glutation vagy a DON-szulfát is (Kluger et al., 2015; Warth et al., 2015). A kötött toxinok képződésének folyamata nem irreverzibilis, ezekből a kötött DON molekulákból hidrolízis révén szabad DON molekulák szabadulhatnak fel. 
Számos publikáció foglalkozik azzal, miként változhat a DON toxin tartalom a kenyér készítésének technológiája során. A folyamatot két lépésben vizsgálják: fermentációs és a sütés szakaszaiban. A fermentációs szakaszt tekintve néhányesetben tapasztaltak DON növekedést, de többnyire nem kaptak változást vagy csökkenést mértek. A sütés fázisában az esetek többségében DON csökkenést mértek, melynek mértéke a cipó térfogatától, hőmérséklettől, sütési időtől változott (Vidal et al., 2014a; Vidal et al., 2014b).

Az olyan tradicionális technológiák, mint a kovászos kenyér készítése újból teret kap. A hagyományos technológia hosszú érlelésü fermentációs folyamatot jelent, ahol tejsavbaktériumok és élesztőgombák játszanak fontos szerepet az aromák, íz kialakításában (Rehman et al., 2006).

Elövizsgálataink során a kovászos kenyérben tapasztalt DON növekedést követően kezdtünk el a kovászra fókuszálni, és vizsgáltuk, hogy a hosszú fermentációs technológia a kovász szabad DON tartalmára miként hat.

\section{Anyag és módszer}

Vizsgálatainkban a Gabonakutató Kft. kiszombori telepéről származó, provokált fuzárium fertőzésnek kitett, mérsékelten rezisztens búzafajtából származó tételeket használtunk fel. A búzából fehér lisztet Brabender senior malom segítségével állítottunk elő. Kovász készítéséhez általános sütőipari élesztőt (Budafoki, Lesaffre Hungary Kft.) használtunk, mellyel híg kovászokat készítettünk $100 \mathrm{~g}$ liszt, $150 \mathrm{ml}$ víz és. 1,5\% élesztő arányban. A vizsgálatokat három ismétlésben végeztük. Az elkészült kovászokat $30^{\circ} \mathrm{C}$-on termosztáltuk. A mintavételezés 5 napon át történt, a kivett mintákból ( $10 \mathrm{ml})$ liofilizálás után a szabad DON toxin meghatározása HPLCMS vizsgálattal történt.

$\mathrm{Az}$ analitikai mérés előkészítéséhez a liofilizált mintákat dörzsmozsárban porítottuk, $1 \mathrm{~g}$ mintát $6 \mathrm{ml}$ acetonitril/víz elegyben $(84 / 16$, v/v) extraháltuk 2,5 órán át rázógépben. Centrifugálás után $(10,000 \mathrm{~g} ; 10 \mathrm{~min}) 1,5 \mathrm{ml}$ felülúszót pároltunk be $40^{\circ} \mathrm{C}$-on, az üledéket $0,5 \mathrm{ml}$ metanol/víz elegyben $(20 / 80$, v/v) oldottuk vissza. A homogén oldatot $0,22 \mu \mathrm{m}$ PTFE membrán filteren (Phenomenex) keresztül szürtük. A kromatográfiás elválasztás C-18-as Varian Polaris oszlopon történt (Agilent 1100 kromatográf) $30^{\circ} \mathrm{C}$-on. Mozgó fázisként víz/metanol elegyet használtunk lineáris gradiens alkalmazásával. Beinjektált mennyiség $5 \mu 1$, áramlási sebesség $0,15 \mathrm{ml} / \mathrm{min}$. Varian 500MSIion Trap tömegspektrofotométert használtuk detektornak (APCI forrás, pozitív ion mód). Teljes spektrumfelvétel történt $50-800 \mathrm{~m} / \mathrm{z}$ között. Mennyiségi DON meghatározás SIM módban történt a megfelelö protonizált molekulára.

Az adatok statisztikai kiértékelése varianciaanalízissel történt (Sváb, 1973).

\section{Eredmények és értékelésük}

A vizsgált híg kovászokban minden esetben szignifikáns növekedést tapasztaltunk a szabad DON mennyiségében (1. ábra): a kezdeti $5,2 \mathrm{mg} / \mathrm{kg}$ átlag tartalomhoz képest kétszeres növekedést tapasztaltunk $(10,7 \mathrm{mg} / \mathrm{kg})$. A növekedés a harmadik napra (69. 
óra) érte el a maximumot, a toxin mennyiségének változása egy telítési görbével jellemezhető. A növekedés időbeni lefolyását szignifikánsan befolyásolta az élesztő mennyisége. A 1,5\%-os élesztőmennyiséget tartalmazó kovászhoz képest a háromszoros (4,5\%-os) élesztőmennyiségủ kovászban már az 5. órában szignifikáns (30\%-os) növekedést tapasztaltunk, míg ugyanezt a mértékü növekedést a 1,5\%-os élesztőtartalom mellett a 21. órában mértük. Az élesztő nélküli kovászban a DON növekedés késleltetve, csak az első nap után indult meg, mely különbség azonban a 45. órában már nem volt kimutatható.

\section{1. ábra: DON tartalom növekedés híg kovászban különböző élesztőmennyiség mellett}

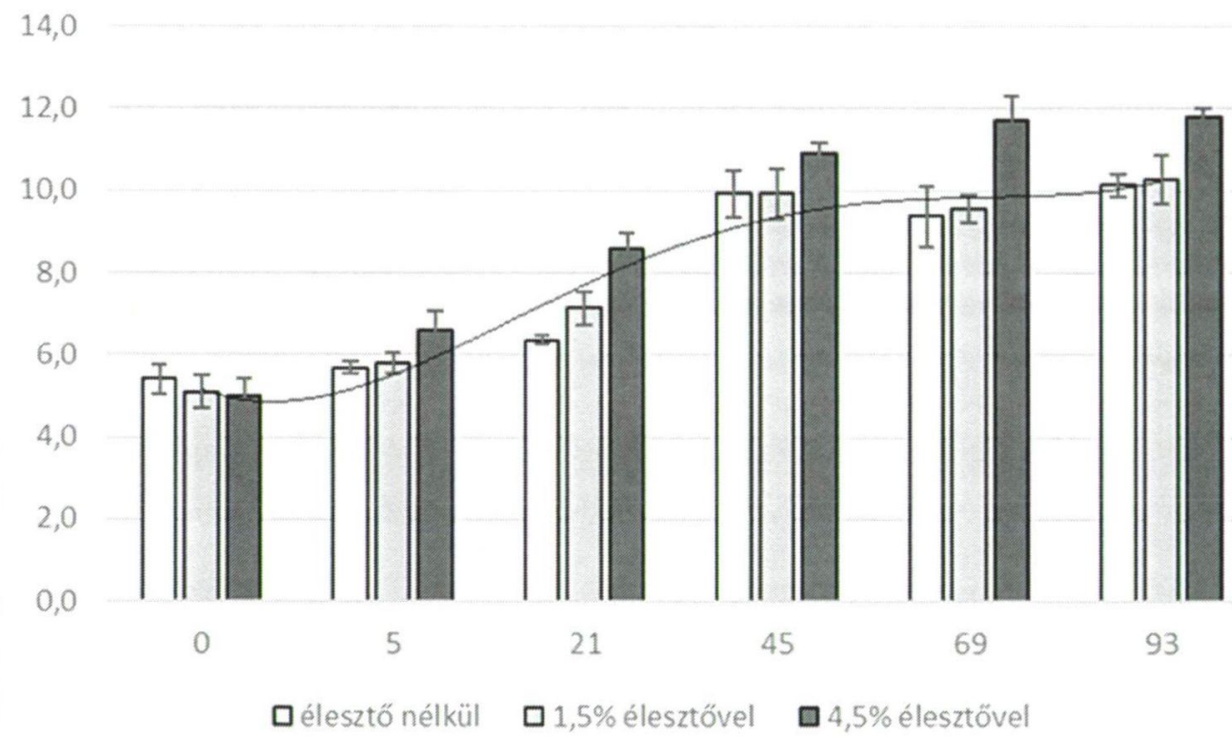

Az LC-MS spektrumok alapján vizsgáltuk az eddig publikált kötött DON (DONhexitol, DON-cisztein, DON-GSH, DON-dihexozid, DON-malonilglükozid, DONszulfát stb.), ill. acetil-DON származékok jelenlétét és mennyiségi változásukat a kovászban. Az eredmények azt mutatták, hogy a kovász készítéséhez felhasznált liszt nem tartalmazott összességében olyan mennyiségü kötött DON vegyületet $(<5 \mathrm{mg} / \mathrm{kg})$, mellyel a kísérleteinkben tapasztalt nagymértékü változás magyarázható volna. A DON növekedés nem származhatott DON termelődésből sem, mivel előzetes PCR és táptalaj vizsgálattal élő Fuzárium gomba (Fusarium culmorum, Fusarium graminearum) jelenlétét kizártuk.

Ismereteink alapján feltételezzük, hogy eddig nem publikált kötött DON molekula áll a nagymértékű DON növekedés hátterében. 


\section{4. Összegzés}

Gabonák élelmezéscélú felhasználásának élelmiszerbiztonsági feltétele a határérték alatti mikotoxin tartalom. Búzát tekintve az EU országaiban, és így Magyarországon is a leggyakrabban elöforduló mikotoxin a DON toxin, melynek „szabad” formájának mérése a gabonafeldolgozó iparban már rutinszerüen zajlik. Kérdés azonban a kötött DON molekulák jelenlétének élelmiszeripari kockázata. Jelen vizsgálat arra mutat rá, hogy előfordulhat gabonákban olyan ismeretlen DON prekurzor, amelyböl jelentős mennyiségü szabad DON képes felszabadulni fermentációs folyamatoknak köszönhetöen, így ennek jelenlétével is számolnunk kellene. A kötött DON vegyületeknek az azonosítása azonban nem tartozik a rutinszerü mérések köré, esetünkben is az ismeretlen DON molekula pontos meghatározása további analitikai kutatómunkát igényel.

\section{Irodalomjegyzék}

Berthiller, F., Crews, C., Dall'Asta, C., Saeger, S. D., Haesaert, G., Karlovsky, P., Oswald, I. P., Seefelder, W., Speijers, G., Stroka, J. (2013): Masked mycotoxins: a review. Mol. Nutr. Food Res, 57 (1): 165-186.

Commission regulation (EC) No 1126/2007 Official Journal of the European Union. L 364/5

Commission regulation (EC) No 881/2006 Official Journal of the European Union. L 364/5

Dall'Asta, C., Berthiller, F. (2016): Masked mycotoxins in food: formation, occurance, and toxicological relevance. Royal society of chemistry, Cambridge.

Kluger, B., Bueschl, C., Lemmens, M., Michlmayr, H., Malachova, A., Koutnik, A., Maloku, I., Berthiller, F., Adam, G., Krska, R., Schuhmacher, R. (2015): Biotransformation of mycotoxin deoxynivalenol in Fusarium resistant and susceptible near isogenic wheat lines. Plos ONE, 10 (3): e01 19656. <http://dx.doi.org/10.1371/journal.pone.01 19656>

Rehman, S., Paterson, A., Piggott, J. (2006): Flavour in sourdough breads: a review. Trends in food science and technology, 17 (10): 557-566.

Sváb J. (1973): Biometriai módszerek a kutatásban. Mezőgazdasági Kiadó, Budapest.

Vidal, A., Marín, S., Morales, H., Ramos, A. J., Sanchis, V. (2014): The fate of deoxynivalenol and ochratoxin A during the breadmaking process, effects of sourdough use and bran content. Food Chem Toxicol., 68 (június): 53-60.

Vidal, A., Morales, H., Sanchis, V., Ramos, A. J., Marín, S. (2014): Stability of DON and OTA during the breadmaking process and determination of process and performance criteria. Food Control. 40 (1): 234-242.

Warth, B., Fruhmann, P., Wiesenberger, G., Kluger, B., Sarkanj, B., Lemmens, M., Hametner, C., Fröhlich, J., Adam, G., Krska, R., Schuhmacher, R. (2015): Deoxynivalenol-sulfates: identification and quantification of novel conjugated (masked) mycotoxins in wheat. Anal. Bioanal. Chem., 407 (4): 1033-1039.

Yazar, S., Omurtag, G. Z. (2008): Fumonisins, trichothecenes and zearalenone in cereals. Int. J. Mol. Sci., doi: $10.3390 / \mathrm{ijms} 9112062$.

Zain, M. E. (2010) Impact of mycotoxins in humans and animals. Journal of Saudi chemical society, doi:10.1016/j.jscs.2010.06.006. 